\title{
Education Destination Determinants Of Chinese Students
}

Yunke He, Okanagan College, Canada

Heather Banham, Okanagan College, Canada

\begin{abstract}
As the focus on international education has changed from international aid to international trade, competition for internationally mobile students has increased. The motivational factors influencing the education destination decision for students from China is of particular significance to destination countries and their educational institutions. This paper explores directly with Chinese students the determinants and motivations on the education destination decision. The primary data is collected from five geographical regions in China. The analysis of the research findings has resulted in some important implications on government policies and institution recruitment strategies.
\end{abstract}

Keywords: Chinese Students; Education Destination Determinants; Study Abroad; Undergraduate Decisions; Internationalization; Country Preference

\section{INTRODUCTION}

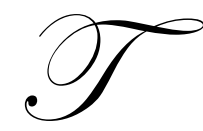

he opportunity for students to study in another country is historically a part of many international development and aid programs. However, over recent decades it has transformed into an international trade initiative and a component of globalization. With this change many nations seek international students as a means of earning export revenues and many educational institutions seek to expand the world view of their students.

Gee (2007) reported that Canada had fallen from one of the top five destinations for international students to $14^{\text {th }}$ position and he exhorted that Canada needed to improve its record on recruiting foreign students. In 2009 Canada attracted approximately $4 \%$ of internationally mobile students (Organization for Economic Co-operation and Development, 2010). According to Institute of International Education (2011), China is the country of origin for approximately $25 \%$ of international students in Canada and is the largest single market segment. This means that understanding the decision determinants for these students can have significant impact for national policies and educational institution practices.

A number of studies have investigated specific source country determinants for postgraduate programs (Eddey \& Baumann, 2008; Gao \& Trent, 2009; Li \& Bray, 2007; Sugahara, Boland, \& Cilloni, 2008), but there is limited literature on research related to the motivational factors that influence the undergraduate educational destination decision of international students. Yet institutions from around the globe, including those based in Canada, are actively seeking to recruit undergraduate students from other countries and cultures as part of their strategic agendas.

According to Labi (2010), postgraduate job prospects are also increasingly factoring into educational destination decisions along with consideration of national and institutional reputation, specific cities and programs. The author's observations are insightful and also present research opportunities to examine other relevant factors and to conduct primary research on this subject.

The overview of the literature reveals a need for more in-depth studies on education destination determinants of Chinese students. To fill in the research gap, this paper explores directly with Chinese students a 
broad range of factors influencing their decision making in selecting schools. The researchers are able to collect primary data from five geographical regions in China. The analysis of the research findings has resulted in some important implications on government policies and institution recruitment strategies.

\section{RESEARCH OBJECTIVE}

The overall research objective is to gain an improved understanding of the education destination determinants of Chinese students seeking to further their undergraduate studies overseas. To achieve these objectives, the following research questions (RQ) are formulated:

RQ 1 Which of the following six countries - Australia, Canada, New Zealand, Singapore, United Kingdom, and United States of America - is the most sought after educational destination by Chinese students?

RQ2 Does the level of awareness of immigration policy of the destination country influence the education destination decision?

RQ3 Does the knowledge of employment opportunities in the destination country influence the education destination decision?

RQ3 Does preferred city size impact the education destination decision?

RQ5 Does desire to avoid certain climatic conditions impact the education destination decision?

RQ6 Do educational institution size, status and public/private structure impact the education destination decision?

RQ7 What are the tuition expectations of Chinese students considering overseas education?

RQ8 What are the future plans of students after completing a degree overseas?

RQ9 What is the relative importance of institutional status, tuition fees, living environment, immigration policies, employment opportunities and employability to Chinese students considering overseas education?

The process to address the research questions is depicted in Figure 1, which shows data collection, statistical analysis of findings, and implications for destination countries and their educational institutions.

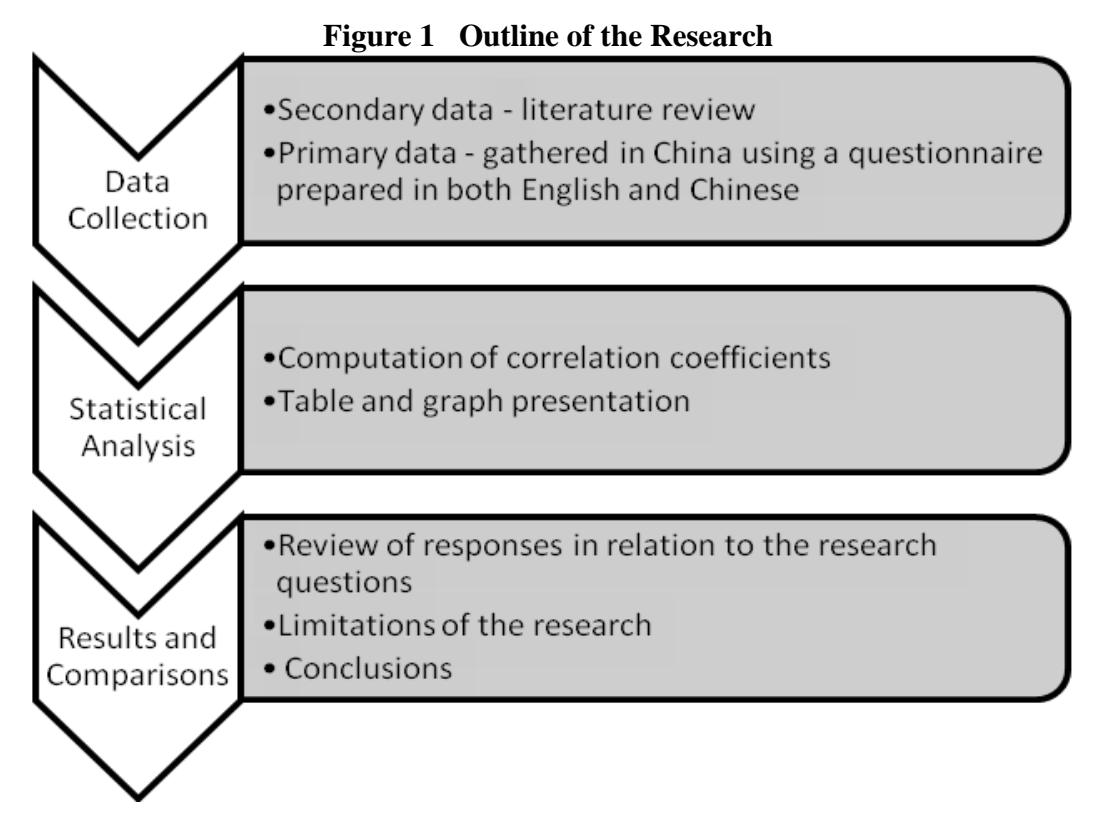

\section{METHODOLOGY}

Primary data collected from a survey is used to investigate factors which influence Chinese students in selecting schools abroad. These factors include immigration policies and employment opportunities in destination countries, the size of the city, the type of climate, the school size, the status/reputation/ranking of the school, private 
vs. public schools, and the range of tuition fees. The researchers also examine the importance of each factor ranked by students in their decision making.

A probability sampling design for the survey would be ideal for this study because it would provide specific error estimates for population parameters and allow the researchers to generalize the results of the population. However, the scope of such a project and the physical and financial resources required to implement this type of sampling design are immense considering the geographic size and population of China. Therefore a nonprobability sampling design is developed. Specifically, judgment samples are used in the study. To increase the representativeness of the samples, primary data are collected from two sources of Chinese students in five different locations.

The first data source is four private Chinese-Canadian high schools, which are located in four coastal provinces and autonomous municipalities. Therefore geographical diversification is also given some consideration. The tuition fees are very high in these four private schools compared to those in the Chinese public high school system and most students are from relatively wealthy families.

The four schools use both Chinese and Canadian high school curricula and intend to blend educational practices from the East and the West. Courses are taught by both Chinese and Canadian teachers. Graduates from Grade 12 receive both Chinese and Canadian graduation certificates and more than 95\% of them plan to study abroad after graduation. In fact, they are actively recruited by Canadian, American, Australian, British and other English-speaking universities in the rest of the world.

The second data source is a joint Chinese-American undergraduate program hosted by a Chinese university. It is located in an interior region. The tuition fees are higher than those of domestic programs at the same university and most students are from the middle and upper-middle class families. In this joint Chinese-American program, courses are taught by both Chinese and American faculty members. It is a " 2 plus 2 " program, i.e. students may complete their first two years in China and second two years in the United States of America, then receive a Bachelor's degree from the American partner university. For those students who wish to complete their four years of study in China, they will receive a Bachelor's degree from the Chinese university. For the purpose of this study, the researchers select first and second year students as respondents.

The two data sources allow the researchers to compare the results between students from high income and middle income families, between different stages of schooling, and other backgrounds.

The questionnaire is purposefully concise and takes about five minutes to complete. The survey questionnaire along with the research proposal is approved by the Okanagan College Research Ethics Board before the research commences. The questionnaire is prepared in both English and Chinese. The Chinese version of the questionnaire is used to ensure there is no impairment in the responses due to possible language barriers. The survey is conducted in late November 2010. The researchers do not have a target number of subjects from each data source. The number of completed questionnaires is dependent on the availability and willingness of subjects to participate at the time of the survey. Coincidentally, the numbers of surveys collected from the two sources happen to be equal: 113 from each data source. The findings are summarized and analyzed in the next section.

\section{FINDINGS AND ANALYSIS}

In addressing the research questions, the results from the survey are reported based on the two data sources described in the previous section: students from the four Chinese-Canadian high schools (CCHS) and students from the Chinese-American undergraduate program (CAUP).

\section{RQ 1 Which of the following six countries - Australia, Canada, New Zealand, Singapore, United Kingdom, and United States of America - is the most sought after educational destination by Chinese students?}

The response rates to this question are very high with $96 \%$ and $89 \%$ from the CCHS students and the CAUP students respectively, which indicates very high importance of country destination to students. Percentages of students selecting each of six countries as their most preferred destinations are shown below: 
Table 1 Country Preference for Educational Destination (\% of respondents)

\begin{tabular}{|c|c|c|c|c|c|c|}
\hline Data Source & Australia & Canada & New Zealand & Singapore & United Kingdom & United States \\
\hline CCHS & 2 & 56 & 1 & 0 & 7 & 31 \\
\hline CAUP & 22 & 11 & 9 & 4 & 14 & 29 \\
\hline
\end{tabular}

These results are presented graphically in Figure 2.

Figure 2 Country Preference for Educational Destination (\% of respondents)

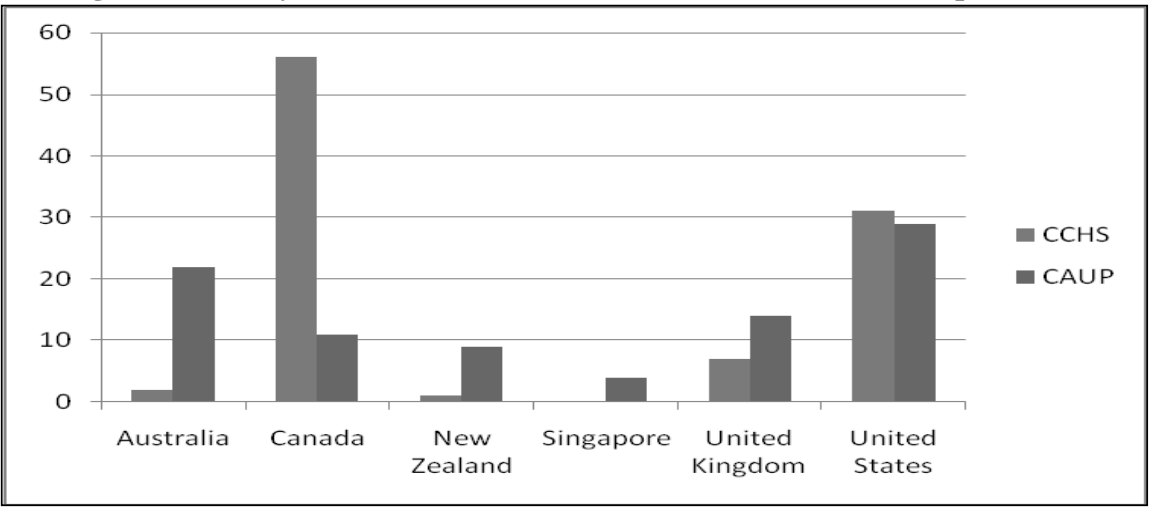

It is not unexpected that $56 \%$ of students from CCHS choose Canada as their most preferred country because their schools adopt Canadian high school curricula. However, the results show that the United States is also a very attractive destination to students from CCHS.

Unexpectedly, only $29 \%$ of students from CAUP choose the United States as their most preferred country in this Chinese-American joint program; while 22\% of them indicate Australia as their first choice.

\section{RQ2 Does the level of awareness of immigration policy of the destination country influence the education} destination decision?

Respondents are asked to indicate their own level of awareness of the immigration policies of their selected country destination. Percentages of students who are highly aware of the immigration policies of destination countries are shown below:

Table 2 Highly Aware of Immigration Policy (\% of respondents)

\begin{tabular}{|c|c|c|c|c|c|c|}
\hline Data Source & Australia & Canada & New Zealand & Singapore & United Kingdom & United States \\
\hline CCHS & 4 & 34 & 1 & 4 & 6 & 19 \\
\hline CAUP & 7 & 2 & 0 & 4 & 4 & 12 \\
\hline
\end{tabular}

Percentages of students who are somewhat aware of the immigration policies of destination countries are shown below:

Table 3 Somewhat Aware of Immigration Policy (\% of respondents)

\begin{tabular}{|c|c|c|c|c|c|c|}
\hline Data Source & Australia & Canada & New Zealand & Singapore & United Kingdom & United States \\
\hline CCHS & 46 & 58 & 12 & 26 & 34 & 56 \\
\hline CAUP & 31 & 30 & 16 & 23 & 29 & 37 \\
\hline
\end{tabular}



below:

Percentages of students who are not aware of the immigration policies of destination countries are shown

Table 4 Not Aware of Immigration Policy (\% of respondents)

\begin{tabular}{|c|c|c|c|c|c|c|}
\hline Data Source & Australia & Canada & New Zealand & Singapore & United Kingdom & United States \\
\hline CCHS & 46 & 8 & 82 & 70 & 56 & 25 \\
\hline CAUP & 60 & 66 & 81 & 70 & 64 & 49 \\
\hline
\end{tabular}

The graphical presentation of this data is shown in Figure 3.

Figure 3 Awareness of Immigration Policies - CCHS Respondents

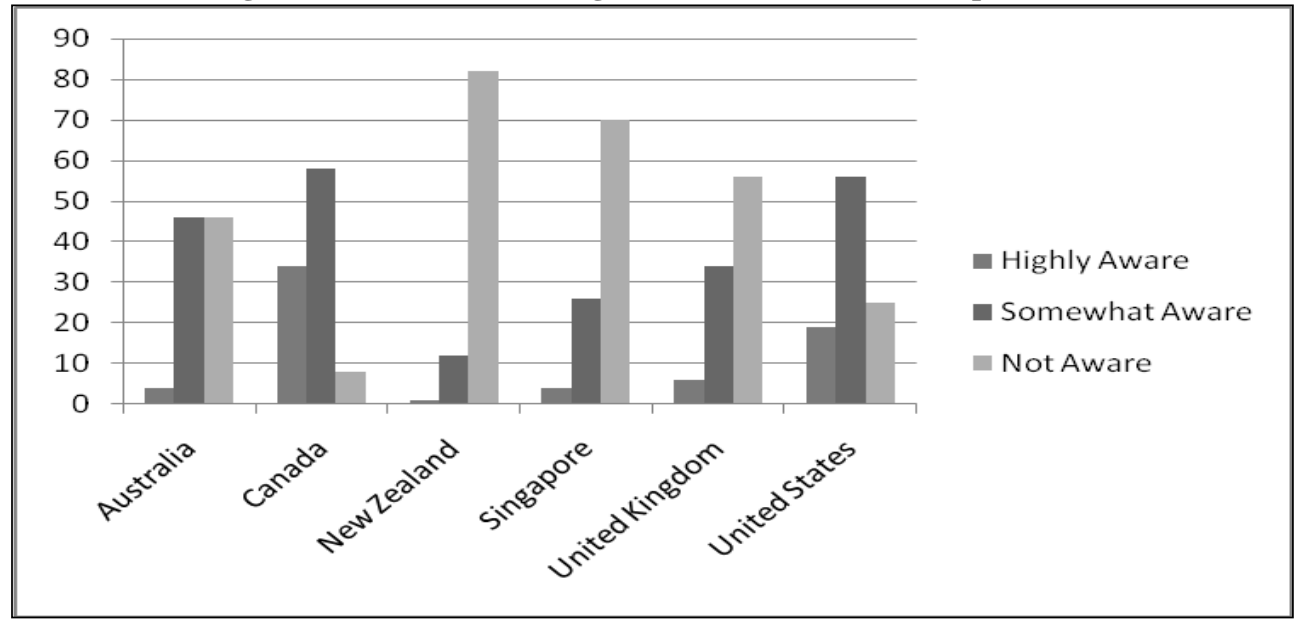

92\% of the CCHS students are either highly aware or somewhat aware of the immigration policies of Canada and $75 \%$ of the same group are either highly aware or somewhat aware of the immigration policies of the United States. Percentages of students who are not aware of the immigration policies of Australia, New Zealand, Singapore and the United Kingdom are 46\%, $82 \%, 70 \%$, and 56\% respectively - much lower degrees of awareness.

Figure 4 Awareness of Immigration Policies -- CAUP Respondents

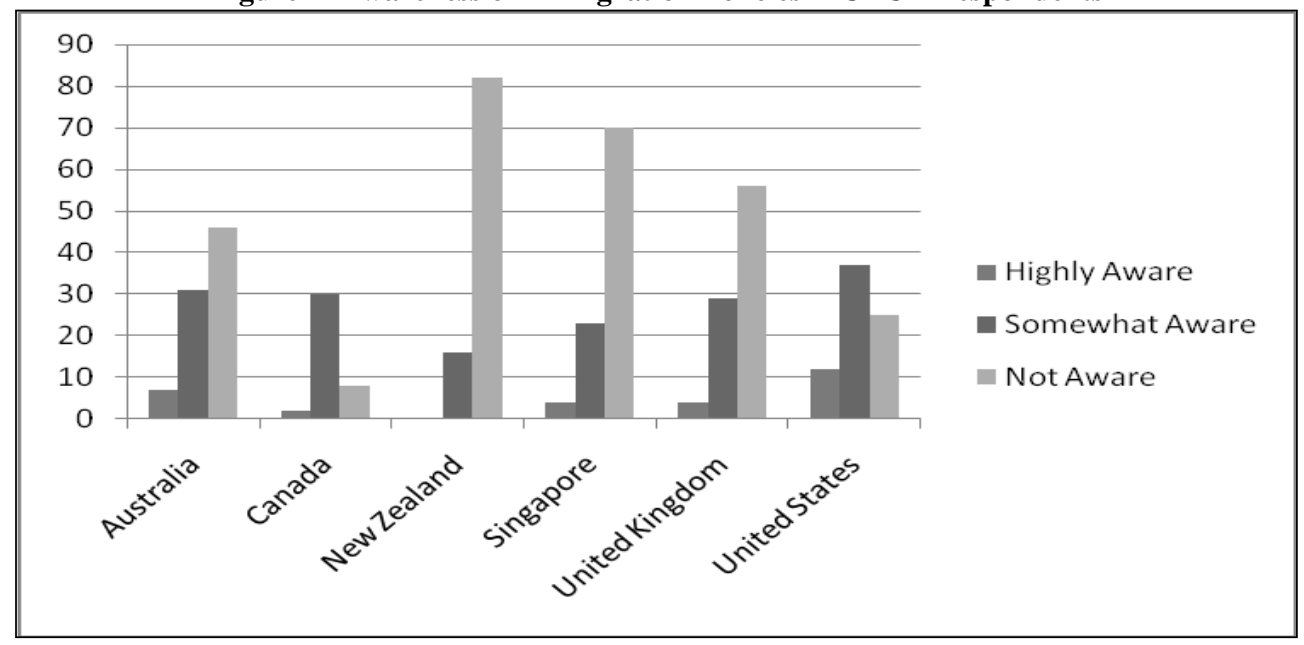


The CAUP students are largely unaware of the immigration policies - with "Not Aware" responses ranging from $49 \%$ (United States) to $81 \%$ (New Zealand).

To further examine the relationship between student responses to their preferred education destination and their awareness of immigration policies in the destination country, three pairs of correlation coefficients are calculated between the percentages of students who select a particular country as their first choice and the percentages of students who are highly/somewhat/not aware of that country's immigration policies. The results are shown below:

Table 5 Relationship of Immigration Policy Level of Awareness to Preferred Education Destination

\begin{tabular}{|c|c|c|c|}
\hline $\begin{array}{c}\text { Data } \\
\text { Source }\end{array}$ & $\begin{array}{c}\text { Correlation with } \\
\text { high awareness }\end{array}$ & $\begin{array}{c}\text { Correlation with } \\
\text { somewhat awareness }\end{array}$ & $\begin{array}{c}\text { Correlation with } \\
\text { no awareness }\end{array}$ \\
\hline CCHS & 0.9963 & 0.7821 & -0.9645 \\
\hline CAUP & 0.8509 & 0.7964 & -0.9699 \\
\hline
\end{tabular}

Three pairs of correlation coefficients indicate strongly positive, positive and strongly negative relationships between the most preferred country and high/somewhat/no awareness of that country's immigration policies respectively. It seems reasonable to conclude: the higher the awareness level of a particular country's immigration policies, the higher the percentage of students choosing it as the most preferred destination; the lower the awareness level of a particular country's immigration policies, the lower the percentage of students choosing it as the most preferred destination. These results explain the correlation between preferred education destination and awareness of immigration policies of that country in a consistent and significant way.

\section{RQ3 Does the knowledge of employment opportunities in the destination country influence the education destination decision?}

Percentages of students who are very knowledgeable about employment opportunities of destination countries are shown below:

Table 6 Very Knowledgeable of Employment Opportunities (\% of respondents)

\begin{tabular}{|c|c|c|c|c|c|c|}
\hline Data Source & Australia & Canada & New Zealand & Singapore & United Kingdom & United States \\
\hline CCHS & 4 & 28 & 2 & 1 & 5 & 20 \\
\hline CAUP & 2 & 1 & 1 & 1 & 4 & 6 \\
\hline
\end{tabular}

Percentages of students who are somewhat knowledgeable about employment opportunities of destination countries are shown below:

Table 7 Somewhat Knowledgeable of Employment Opportunities (\% of respondents)

\begin{tabular}{|c|c|c|c|c|c|c|}
\hline Data Source & Australia & Canada & New Zealand & Singapore & United Kingdom & United States \\
\hline CCHS & 35 & 55 & 13 & 22 & 30 & 52 \\
\hline CAUP & 29 & 27 & 13 & 27 & 24 & 48 \\
\hline
\end{tabular}

Percentages of students who are not knowledgeable about employment opportunities of destination countries are shown below:

Table 8 Not Knowledgeable of Employment Opportunities (\% of respondents)

\begin{tabular}{|c|c|c|c|c|c|c|}
\hline Data Source & Australia & Canada & New Zealand & Singapore & United Kingdom & United States \\
\hline CCHS & 54 & 15 & 78 & 70 & 58 & 25 \\
\hline CAUP & 67 & 71 & 84 & 70 & 71 & 46 \\
\hline
\end{tabular}


Percentages of the CCHS students indicating either "very knowledgeable" or "somewhat knowledgeable" are $83 \%$ for Canada and $72 \%$ for the United States respectively.

To further examine the relationship between student responses to their preferred education destination and their knowledge of employment opportunities in the destination country, three pairs of correlation coefficients are calculated between the percentages of students who make a particular country as their first choice and the percentages of students who are very/somewhat/not knowledgeable about that country's employment opportunities. The results are shown below:

Table 9 Relationship of Employment Opportunities Knowledge to Preferred Education Destination

\begin{tabular}{|c|c|c|c|}
\hline $\begin{array}{c}\text { Data } \\
\text { source }\end{array}$ & $\begin{array}{c}\text { Correlation with } \\
\text { very knowledgeable }\end{array}$ & $\begin{array}{c}\text { Correlation with } \\
\text { somewhat knowledgeable }\end{array}$ & $\begin{array}{c}\text { Correlation with } \\
\text { no knowledge }\end{array}$ \\
\hline CCHS & 0.9902 & 0.8689 & -0.9353 \\
\hline CAUP & 0.8166 & 0.7686 & -0.9525 \\
\hline
\end{tabular}

Three pairs of correlation coefficients indicate strongly positive, positive and strongly negative relationships between the most preferred country and being very/somewhat/not knowledgeable of that country's employment opportunities respectively. It seems reasonable to conclude: the greater the knowledge that students have of a particular country's employment opportunities, the higher the percentage of students choosing it as the most preferred destination; the less knowledge of a particular country's employment opportunities, the lower the percentage of students choosing it as the most preferred destination. These results explain the correlation between responses to preferred education destination country and knowledge of employment opportunities in a consistent and significant way.

Now it is understandable why $31 \%$ of students from the four Chinese-Canadian high schools make the United States as their first choice and why $22 \%$ of students from the Chinese-American joint program make Australia as their first choice. The United States government actively promotes its country in China. The Voice of America radio station funded by the American government is just an example: for more than a half century it has been broadcasting in Chinese language and covering most territories of China. Australia has been accepting significant numbers of Chinese professional and investor immigrants in recent years; it has also been successfully promoting itself as an education export country in China. Therefore it is suggested that the high profiles of these two countries in China help attract Chinese students to their education systems.

Based on the above findings and analysis of the responses in relation to the preferred education destination and knowledge of immigration policies and employment opportunities, an important policy implication emerges: successful promotion of a destination country also pays dividends in the education sector.

\section{RQ4 Does preferred city size impact the education destination decision?}

The response rates to this question are $67 \%$ and $61 \%$ from CCHS and CAUP respectively; meaning that $33 \%$ and $39 \%$ of students from these two sources do not consider the city size as a decision factor in selecting schools. Percentages of students who prefer different city sizes are shown below:

Table 10 City Size Preference (\% of respondents)

\begin{tabular}{|c|c|c|c|}
\hline $\begin{array}{c}\text { Data } \\
\text { Source }\end{array}$ & $\begin{array}{c}\text { 1 million residents } \\
\text { or more }\end{array}$ & $\begin{array}{c}\boldsymbol{> 0 . 3} \text { million } \\
\text { but < 1 million }\end{array}$ & $\begin{array}{c}\text { 0.3 million residents } \\
\text { or less }\end{array}$ \\
\hline CCHS & 24 & 34 & 10 \\
\hline CAUP & 24 & 27 & 10 \\
\hline
\end{tabular}

Relatively speaking, the city size is not a very significant factor. However, the findings do present opportunities for recruiting schools to emphasize the advantages of their own city size to attract their target students. 


\section{RQ5 Does desire to avoid certain climatic conditions impact the education destination decision?}

Respondents are able to express a desire to avoid more than one type of climate and therefore the sum of the responses is greater than the number of total participants. Numbers of students who want to avoid particular type(s) of climate are shown below:

Table 11 Climate Avoidance Preference

\begin{tabular}{|c|c|c|c|}
\hline Data Source & Hot and humid summer & Very cold winter & Long rainy season \\
\hline CCHS & 35 & 45 & 48 \\
\hline CAUP & 65 & 35 & 43 \\
\hline
\end{tabular}

These numbers may be overstated for two reasons. Firstly, most Chinese universities do not provide comfortable heating during the winter and do not have air conditioning during the summer (the researchers had firsthand experience while teaching in China as visiting professors). Secondly, students may not be aware of the heating and cooling standard in destination countries. As a result, the findings may just reflect students' own experience in China. However, the findings do reveal the need for recruiters to explain to Chinese students how little the outdoor weather conditions actually affect people's indoor daily life under these "to avoid" types of climate in destination countries.

\section{RQ6 Do educational institution size, status and public/private structure impact the education destination decision?}

The response rates to the question about institutional size are $61 \%$ and $64 \%$ from CCHS and CAUP respectively; i.e. $39 \%$ and $36 \%$ of students from these two sources do not consider the school size as a factor in decision making. Percentages of students who prefer different school sizes are shown below:

Table 12 Institutional Size Preference (\% of respondents)

\begin{tabular}{|c|c|c|c|}
\hline Data Source & $\mathbf{3 0 , 0 0 0}$ students or more & $\mathbf{> 1 0 , 0 0 0}$ but $<\mathbf{3 0 , 0 0 0}$ & $\mathbf{1 0 , 0 0 0}$ students or less \\
\hline CCHS & 12 & 30 & 19 \\
\hline CAUP & 19 & 32 & 13 \\
\hline
\end{tabular}

Relatively speaking, the school size is not a very significant factor. However, a recruiting school may emphasize the advantages of its school size to attract its target students.

The response rates to the question about preference for school status are $90 \%$ and $92 \%$ from CCHS and CAUP respectively, which indicate the importance of the ranking and reputation of schools to them. Percentages of students who prefer different tiers of schools are shown below:

Table 13 School Status and Reputation Preference (\% of respondents)

\begin{tabular}{|c|c|c|c|c|}
\hline Data Source & Top & Well-known & Not well known & Unknown \\
\hline CCHS & 39 & 50 & 2 & 0 \\
\hline CAUP & 49 & 41 & 3 & 0 \\
\hline
\end{tabular}

These numbers reflect a degree of unrealistic expectations of respondents. In fact only $2 \%$ or $3 \%$ of students have the potential to meet the admission requirements of the top tier universities in destination countries; yet $39 \%$ of the CCHS and $49 \%$ of the CAUP group state that they seek a "Top" university. Note that the "Top" university in the Chinese version of the questionnaire literally means the "peak of the top" university and therefore leaves no doubt as to interpretation of the question. However, the emphasis on status is less surprising when placed in its cultural and societal context. 
The research findings present a challenge to many recruiting schools: students have unrealistic expectations about their ability to be accepted to the top ranking schools. The students need greater awareness of their aspirations to attend the best schools vis-à-vis their ability to meet the related admission standards. This is not an easy task and may well require a long term effort.

The students are also asked to consider whether they preferred public or private institutions. The response rates to this question are 54\% and 73\% from CCHS and CAUP respectively; $46 \%$ and $27 \%$ of students from these two sources do not consider a public or private as a factor in decision making. Percentages of students who prefer public or private schools are shown below:

Table 14 Public vs. Private school Preference (\% of respondents)

\begin{tabular}{|c|c|c|}
\hline Data Source & Public & Private \\
\hline CCHS & 40 & 14 \\
\hline CAUP & 64 & 10 \\
\hline
\end{tabular}

Overall, more students prefer public to private schools. This may be largely explained by the fact that almost all universities in China are public institutions and therefore private universities are an unfamiliar territory to Chinese students. Besides, the scandals of a small number of bankrupted private educational institutions (mainly English language preparatory schools) in destination countries in recent years may also be making a contribution to this result. A significantly higher percentage of students from CAUP indicate a preference for public compared to private schools. This may be explained by the students' own experiences in a public university (CAUP) and in private schools (CCHS) respectively.

\section{RQ7 What are the tuition expectations of Chinese students considering overseas education?}

Students are asked to consider the maximum tuition fees they would be willing to pay per academic year in Chinese currency (CNY). The response rates to this question are 99\% from both data sources, which indicate the very high importance of tuition fees to them. Percentages of students whose willingness to pay the maximum tuition fees are shown below ( $1 \mathrm{USD} \approx 6.6 \mathrm{CNY}$ at the time of the survey):

Table 15 Tuition Expectations (\% of respondents)

\begin{tabular}{|c|c|c|c|c|c|}
\hline Data Source & $\mathbf{7 5 , 0 0 0}$ CNY & $\mathbf{1 0 0 , 0 0 0} \mathbf{C N Y}$ & $\mathbf{1 5 0 , 0 0 0}$ CNY & $\mathbf{2 0 0 , 0 0 0}$ CNY & $>\mathbf{2 0 0 , 0 0 0}$ CNY \\
\hline CCHS & 1 & 19 & 28 & 35 & 16 \\
\hline CAUP & 50 & 28 & 13 & 5 & 2 \\
\hline
\end{tabular}

Two observations from the findings are worth mentioning. Firstly, the family income gap between the CCHS and the CAUP students is evident. This confirms the background information of the student bodies of these two sources. Secondly, students' (particularly the CAUP students') unrealistic expectations on their desire to attend the top tier universities and their inability to afford the top university tuition fees are also evident. Again, students need to be educated in terms of the top tier university status and the associated high tuition fees. At the same time, the research findings also present an opportunity for schools charging relatively low tuition fees to identify their potential target students.

\section{RQ8 What are the future plans of students after completing a degree overseas?}

The response rates to this question relating to future plans are $100 \%$ and $98 \%$ from CCHS and CAUP respectively. However, $46 \%$ of the CCHS students and $37 \%$ of the CAUP students indicate that they will decide later. Percentages of students who indicate their future plans after completing their studies are shown below: 
Table 16 Future Plans of Potentially Mobile Students (\% of respondents)

\begin{tabular}{|c|c|c|c|}
\hline Data Source & Return to China & Search for employment abroad & Decide later \\
\hline CCHS & 16 & 38 & 46 \\
\hline CAUP & 46 & 15 & 37 \\
\hline
\end{tabular}

The CCHS students who plan to return to China are 30 percentage points lower than the CAUP students, while the CCHS students who plan to search for employment abroad are 23 percentage points higher than the CAUP students. These significant gaps may be explained by at least three factors. Firstly, compared to the CAUP students, the CCHS students have much more exposure to the western world in their curricula and extracurricular activities. As a result, they are more knowledgeable about the western society. This is already evident in their responses to the questions relating to the immigration policies and employment opportunities in education destination countries. Secondly, the CCHS students have better English language capacity and feel more confident that they will succeed in the job market abroad. This is confirmed by observations by the researchers in conversations with both CCHS and CAUP students. Finally, most CCHS students are from wealthy families, many of whom have a tendency to migrate to destination countries as entrepreneur or investor immigrants. This trend is widely reported by the media in destination countries such as Canada and the United States.

RQ9 What is the relative importance of institutional status, tuition fees, living environment, immigration policies, employment opportunities and employability to the education destination decision of Chinese students considering overseas education?

This is a concluding question asking students to indicate the most important factor in their decision making on educational destination. 98\% of students from both CCHS and CAUP respond to this question. Percentages of students who identify their number one decision factors are shown below:

Table 17 Relative Importance of Factors in the Education Destination Decision (\% of respondents)

\begin{tabular}{|c|c|c|c|c|c|}
\hline $\begin{array}{c}\text { Data } \\
\text { Source }\end{array}$ & $\begin{array}{c}\text { School } \\
\text { status }\end{array}$ & $\begin{array}{c}\text { Tuition } \\
\text { fees }\end{array}$ & $\begin{array}{c}\text { Living } \\
\text { environment }\end{array}$ & $\begin{array}{c}\text { Immigration and } \\
\text { employment }\end{array}$ & $\begin{array}{c}\text { Employability } \\
\text { of graduates }\end{array}$ \\
\hline CCHS & 41 & 2 & 19 & 18 & 19 \\
\hline CAUP & 22 & 29 & 13 & 16 & 18 \\
\hline
\end{tabular}

There is no ambiguity that the school status (ranking, reputation, etc.) is the most important decision factor for the CCHS students; and the second most important decision factor for the CAUP students. As analyzed in the section relating specifically to institutional status, many of these students need to have a reality check because they are not well informed about the admission requirements of different tiers of universities. While they may anticipate that school status will be a very important determinant of their education destination decision, it may not be their number one determining factor when considering the reality of offers or rejections received. For many recruiters, the research findings present a real opportunity to identify and educate their target students.

The affordability of the tuition fees is a very concrete measure and therefore the validity of student responses is very high. 29\% of the CAUP students rank tuition fees as the top decision factor. This segment of students is potentially large in China and therefore is an important market for schools charging relatively low tuition fees.

The living environment determinant includes safety, climate, city size and school size. As discussed earlier in this paper, neither the city size nor the school size is a significant factor. Furthermore, student responses to the climate question may be biased. Then the safety issue must be a major concern. It is certainly a good strategy for schools located in areas with low crime rates to present the facts to students.

Immigration policies and employment opportunities are ranked as the top decision factor by $18 \%$ and $16 \%$ of students from CCHS and CAUP respectively. These numbers are significant. Schools from countries with low birth rates, welcoming immigration policies and low unemployment rates are in a very favourable position to 
emphasize these advantages and therefore are able to achieve their recruitment goals.

Finally, employability of graduates of a school is ranked as the top decision factor by $19 \%$ and $18 \%$ of students from CCHS and CAUP respectively. From the researchers' point of view, this factor may actually play the most important role in selecting schools. This factor has high validity; it can be measured using concrete statistics such as percentages of graduates employed in relevant fields within six or twelve months after graduation. Such measures provide compelling evidence. Therefore schools with excellent records in this regard are in the best position to present appropriate statistics as a highly effective recruiting tool.

To summarize the results, the responses in Table 17 are reclassified into three categories: institutional, living environment, and destination country influences, as presented below:

Table 18 Influence Categories Relative to the Destination Decision

\begin{tabular}{|l|l|l|}
\hline \multicolumn{1}{|c|}{ Institutional Influences } & \multicolumn{1}{|c|}{ Living Environment } & \multicolumn{1}{|c|}{ Destination Country Influences } \\
\hline School Status & Safety & Immigration Policy \\
\hline Tuition Costs & City Size & Employment Opportunities \\
\hline Employability of graduates & Climatic Factors & \\
\hline & School Size & \\
\hline
\end{tabular}

The response rates for each influence category are graphed as shown below:

Figure 5 Influence Categories for Destination Decision

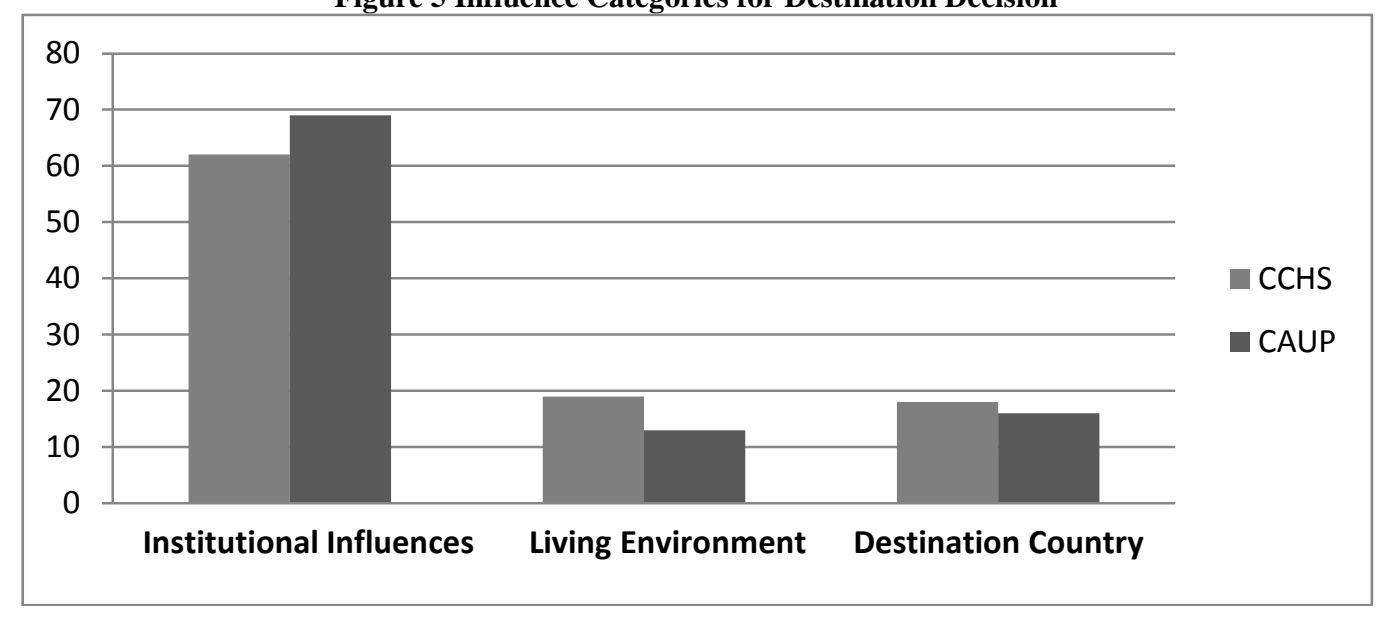

Institutional influences of school status, tuition costs, and the employability of graduates are ranked highest by both CCHS (62\%) and CAUP (69\%) students although they are higher overall for the CAUP students. The influences of the immigration policy and employment opportunities are ranked by $18 \%$ of the CCHS students and $16 \%$ of the CAUP students. Living environment influences are ranked by $19 \%$ of the CCHS students and $13 \%$ of the CAUP students. Overall, institutional influences are dominating factors. As a result, institutional strategies can play a very important role in recruitment activities and outcomes.

\section{LIMITATIONS}

This is an exploratory survey to improve understanding of the educational destination determinants in four private Chinese-Canadian high schools and a joint Chinese-American undergraduate program. Judgement samples are used in the survey despite the consideration of diversification in five geographical regions. In addition, the presence of the researchers (professors) in the survey process (providing information, distributing and collecting 
questionnaires) may have influence on student responses due to the culture of respect for professors in the Chinese society. Therefore the researchers do not intend to generalize the results to the whole population.

\section{CONCLUSIONS}

The motivational factors influencing the education destination decision for the students from China is of particular significance to destination countries and their educational institutions. Using the primary data and the analytical tools described in the preceding section, this study provides greater understanding of these factors and important implications on government policies and institutional recruitment strategies.

The analysis of the research findings shows strong positive correlation between the preferred choice of education destination and awareness/knowledge of immigration policies and employment opportunities in a destination country. An important government policy implication is that successful promotion of a destination country has potential benefits to its education sector.

There is no ambiguity that the school status (ranking, reputation, etc.) is perhaps the most important decision factor for Chinese students at least in the initial stage of selecting schools. However, the analysis of the research findings provides some important recruiting strategies for most universities and colleges, which are not the top ranking institutions. Firstly, students need greater awareness of their aspirations to attend the best schools vis-àvis their ability to meet the required admission standards and to afford the related tuition fees. This is not an easy task and may well require a long term effort. Secondly, institutions from countries with low birth rates, welcoming immigration policies and low unemployment rates are in a very favourable position to emphasize these advantages and therefore are able to attract Chinese students. Thirdly, institutions with excellent records in graduate employability are in the best position to present appropriate statistics to potential students as a highly effective recruiting tool. After all, graduate employment rates reflect the overall quality of education of an institution. Fourthly, tuition costs are also very important to the emerging group of middle class families in China. This segment of students is potentially huge and therefore is an important market for schools charging relatively low tuition fees. Finally, institutions may also indentify their target students based on the student preferences to certain aspects of the living environment such as safety, climate, city size, school size, public or private school; then promote their institutions to these target students and achieve the recruitment goals.

\section{AUTHOR INFORMATION}

Yunke He received his $\mathrm{PhD}$ degree from McMaster University in Canada and is a CFA charterholder. He teaches at the Okanagan School of Business and has published in academic journals including American Journal of Business Education, International Business \& Economics Research Journal, Journal of International Business and Economics, Journal of Investment Economics, and Journal of Quantitative Economics. E-mail: yhe@okanagan.bc.ca

Heather Banham earned her Doctor of Business Administration degree at the University of Southern Queensland, Australia and holds her professional accounting designation as a CGA (Certified General Accountant) in Canada. She is currently serving as Dean in the Okanagan School of Business at Okanagan College and her research interests include organizational change and small and medium enterprises. E-mail: hbanham@okanagan.bc.ca

\section{REFERENCES}

1. Eddey, P., \& Baumann, C. (2009). Graduate business education: profiling successful students and its relevance for marketing and recruitment policy. Journal of Education for Business, January/February, pp. $160-167$.

2. Gao, X., \& Trent, J. (2009). Understanding mainland Chinese students' motivations for choosing teacher education programmes in Hong Kong. Journal of Education for Teaching, 35(2), 145-159.

3. Gee, M. (2007, November 7). Canada must fix "pathetic" record on recruiting foreign students. The Globe and Mail, p. B14.

4. Institute of International Education. (2011). Retrieved from http://www.atlas.iienetwork.org/?p=48027 
5. Labi, A. (2010). What do international students want? Jobs. Chronicle of Higher Education, 56(28), pp. A32-34.

6. Li, M., \& Bray, M. (2007). Cross border flows of students for higher education: Push-pull factors and motivations of mainland Chinese students in Hong Kong and Macau. Higher Education, 53, 791-818.

7. Organization for Economic Co-operation and Development. (2010). Education at a Glance. Retrieved from http://www.atlas.iienetwork.org/?p=48027

8. Sugahara, S., Boland, G., \& Cilloni, A. (2008). Factors influencing students' choice of an accounting major in Australia. Accounting Education: An International Journal, 17, S37-S54. 


\section{NOTES}

